\title{
The effect of trace amounts of tissue factor on thrombin generation in platelet rich plasma, its inhibition by heparin
}

Citation for published version (APA):

Beguin, S., Lindhout, T., \& Hemker, H. C. (1989). The effect of trace amounts of tissue factor on thrombin generation in platelet rich plasma, its inhibition by heparin. Thrombosis and Haemostasis, 61(1), 25-29. https://doi.org/10.1055/s-0038-1646521

Document status and date:

Published: 01/01/1989

DOI:

10.1055/s-0038-1646521

Document Version:

Publisher's PDF, also known as Version of record

Please check the document version of this publication:

- A submitted manuscript is the version of the article upon submission and before peer-review. There can be important differences between the submitted version and the official published version of record.

People interested in the research are advised to contact the author for the final version of the publication, or visit the DOI to the publisher's website.

- The final author version and the galley proof are versions of the publication after peer review.

- The final published version features the final layout of the paper including the volume, issue and page numbers.

Link to publication

\footnotetext{
General rights rights.

- You may freely distribute the URL identifying the publication in the public portal. please follow below link for the End User Agreement:

www.umlib.nl/taverne-license

Take down policy

If you believe that this document breaches copyright please contact us at:

repository@maastrichtuniversity.nl

providing details and we will investigate your claim.
}

Copyright and moral rights for the publications made accessible in the public portal are retained by the authors and/or other copyright owners and it is a condition of accessing publications that users recognise and abide by the legal requirements associated with these

- Users may download and print one copy of any publication from the public portal for the purpose of private study or research.

- You may not further distribute the material or use it for any profit-making activity or commercial gain

If the publication is distributed under the terms of Article 25fa of the Dutch Copyright Act, indicated by the "Taverne" license above, 


\title{
The Effect of Trace Amounts of Tissue Factor on Thrombin Generation in Platelet Rich Plasma, its Inhibition by Heparin
}

\author{
S. Béguin, T. Lindhout, and H. C. Hemker \\ From the Department of Biochemistry, University of Limburg, Maastricht, The Netherlands
}

\begin{abstract}
Key words
Platelets - Tissue factor - Thrombin - Heparin
\end{abstract}

\section{Summary}

Amounts of human brain thromboplastin that do not stimulate thrombin generation in platelet poor plasma, were shown to advance by about $4 \mathrm{~min}$ an explosive formation of thrombin that occurs after recalcification in the presence of blood platelets. This synergistic effect is inhibited by the specific thrombin inhibitor hirudin and mimicked by adding low concentrations $(<5 n M)$ of thrombin to platelet rich plasma. It is our conciusion that small amounts of thrombin, generated under the influence of thromboplastin induced procoagulant activity in the blood platelets. This activity is most likely mainly due to procoagulant phospholipids. Heparin inhibits this effect and retards the explosive thrombin formation. It does not, however, diminish the peak amount of thrombin eventually formed. because heparin neutralizing material released from the activated platelets quenches the heparin effect.

\section{Introduction}

Thrombin formation and blood platelet reactions are intimately linked in haemostasis and thrombosis. Thrombin is the most potent biological platelet activator and activated platelets have important procoagulant properties. The concentration of thrombin necessary to trigger a half maximal platelet reaction is significantly lower than that of other physiological activators (ADP, thromboxane $A_{2}$, PAF-acether) $(1,2)$. The membrane of the intact platelets can undergo a transbilayer rearrangement of its phospholipids that makes procoagulant phospholipids (mainly phosphatidyl serine) available at the surface of the intact cell. In washed platelets at a concentration of $10^{6}$ platelets $/ \mathrm{ml}$, thrombin plus collagen is the specific trigger for this process $(2,3)$. Activated platelets release a variety of substances, including coagulation factor $\mathrm{V}$ and platelet factor 4 (PF 4), a protein that neutralizes heparin (4-8). It also has been reported that ADP activated platelets trigger coagulation via a factor XII dependent pathway and that collagen activated platelets cause coagulation in a factor XI dependent pathway that bypasses factor XII $(9,10)$.

From these phenomena, observed mostly with isolated platelets, it is clear that in vivo there must exist several forms of close cooperation between the blood coagulation system and platelets. In vivo, haemostasis will usually be started by the release of tissue factor from wounded cells. Tissue factor is a lipoprotein, present in most mammalian cells but not in blood

Correspondence to: Dr. H. C. Hemker, Dept. of Biochemistry, University of Limburg, P.O. Box 616, 6200 MD Maastricht, The Netherlands platelets. It activates factor VII and thus starts the reaction sequence that leads to thrombin formation (11). In order to investigate the interplay between tissue factor, blood platelets and the plasmatic coagulation factors under in vitro conditions that approach the in vivo situation, we have compared the influence of human brain thromboplastin on thrombin generation in platelet rich and platelet poor plasma.

We found that concentrations of thromboplastin that are without effect on platelet poor plasma, significantly advance the generation of thrombin in platelet rich plasma. Unfractionated heparin inhibited the onset of thrombin generation but not the thrombin yield.

\section{Materials and Methods}

Buffers: A: $0.05 \mathrm{M}$ Tris, $0.1 \mathrm{M} \mathrm{NaCl}, \mathrm{pH} 7.35$. B: $0.05 \mathrm{M}$ Tris, 0.1 M $\mathrm{NaCl}, 20 \mathrm{mM}$ EDTA, $0.5 \mathrm{mg} / \mathrm{ml}$ ovalbumin. $\mathrm{pH} 7.9$.

Calcium chloride $0.1 \mathrm{M}$ adjusted to $\mathrm{pH} 7.35$.

Chromogenic substrate. S2238 (Hd-Phe-Pip-Arg-p-nitroanilide) was supplied by AB Kabi Diagnostica (Stockholm).

Human brain thromboplastin was used as a source of tissue factor. It was prepared according to Owren and Aas (12), homogenized in a. Potter Elvehjem homogeniser for $3 \mathrm{~min}$. centrifugated at $2,000 \mathrm{~g}$ for $15 \mathrm{~min}$ and stored at $-20^{\circ} \mathrm{C}$ in $0.1 \mathrm{ml}$ aliquots. Before use it was thawed. diluted with $0.1 \mathrm{M}$ calcium chloride adjusted to $\mathrm{pH} 7.35$ and preincubated $1 \mathrm{hr}$ at $37^{\circ} \mathrm{C}$. Hirudin was obtained from Sigma (St. Louis, USA).

Platelet rich plasma was obtained by centrifugation $(200 \times \mathrm{g}, 15 \mathrm{~min})$ of freshly drawn citrated blood from a fasting donor; 1 volume trisodium. citrate $0.13 \mathrm{M}$ to 9 volumes blood. The platelet count was adjusted to $3 \times 10^{8} / \mathrm{ml}$ with homologous platelet poor plasma (centrifuged for $15 \mathrm{~min}$ at $10,000 \times \mathrm{g}$ ). Plastic tubes and pipettes were used throughout so as to minimize contact activation.

\section{Thrombin Generation}

The reaction mixture consisted of $240 \mu \mathrm{l}$ piasma and $60 \mu \mathrm{l}$ of buffer $\mathrm{A}$ with or without heparin. The samples were kept at $37^{\circ} \mathrm{C}$ and magnetically stirred. Thrombin formation was started by addition of $60 \mu \mathrm{l}$ of $\mathrm{CaCl}_{2}$ $(0.1 \mathrm{M})$ in which thromboplastin was diluted to the desired concentration.

In order to obtain comparable results independent of platelet aging, two to four experiments were run in parallel. At $10 \mathrm{sec}$ intervals a $10 \mu \mathrm{l}$ sample was taken from each of the mixtures and tested for thrombin. In this way the sampling interval for each mixture is $20-40 \mathrm{sec}$. A computerised registration of sampling times was used (13). The plasma could not be previously defibrinated as this would cause loss of the platelets. A plastic rod was placed in the samples and as soon as the clot was formed it was wound on the rod and removed. This did not interfere with the $10 \mathrm{sec}$ sampling rhythm. The $10 \mu \mathrm{l}$ samples were transferred to

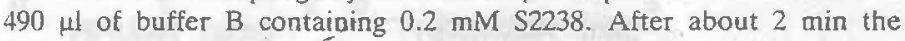
reaction was stopped with $300 \mu \mathrm{l}$ of concentrated acetic acid. The time of stopping the reaction was again recorded by the computer. Optical densities (O.D.) were measured in an LKB Ultrospec II spectrophotometer at $405 \mathrm{~nm}$. From the optical density the recorded incubation inter$\mathrm{val}$ and the proportionality factor (1 O.D. unit/min $=725 \mathrm{nmol}$ thrombin/l) the computer calculated the thrombin content of the samples. 
$\mathrm{V}_{\mathrm{a}}$ can be considered to be roughly equivalent to the contribution of $3 \times 10^{8}$ activated platelets $/ \mathrm{ml}(2,3,14)$.

The addition of factor $\mathrm{V}_{\mathrm{a}}$ to platelet rich plasma has a relatively minor effect on thromboplastin induced thrombin generation. It increases the peak amount of thrombin observed in the burst by about $10 \%$ and slightly shortens the lag time. Phospholipids, however, caused a 2 -fold higher thrombin yield when added to platelet rich plasma in the absence of thromboplastin. When platelet rich plasma was activated by thromboplastin, additional phospholipid had, no effect on thrombin generation (Fig. 5) and shortened the lag time appreciably. When factor $V_{a}$ and phospholipids are added together the effect was not significantly greater than that of phospholipid alone. These results indicate that phospholipids are rate limiting to thrombin generation in normal plasma under our conditions.

Thus it seems that thrombin, in concentrations of less than $5 \mathrm{nM}$, under the influence of small amounts of thromboplastin during the lag time provokes a procoagulant reaction in blood platelets that enables the plasmatic clotting factors to produce a burst of thrombin formation of $100-200 \mathrm{nM}$. Of the known procoagulant functions of the platelets the exposure of procoagulant phospholipids is the most likely to produce this effect.

\section{Effect of Heparin}

When heparin is added to platelet rich plasma in concentrations of up to $0.3 \mathrm{U} / \mathrm{ml}$ the lag phase is prolonged but, surprisingly, hardly any decrease is seen of the amount of thrombin eventually produced in the burst (Fig. 6). In contrast, heparin, when added to platelet poor plasma in these concentrations causes an important inhibition (more than 90\%) of the amount of thrombin formed (15). As can be seen from Fig. 7 this difference between the action of heparin on platelet rich plasma and on platelet poor plasma can be explained by the release of heparin neutralizing material (in all probability platelet factor 4) from the triggered platelets. Heparin $(0.5 \mathrm{U} / \mathrm{ml})$ will cause only $20 \%$ inhibition of the peak of thrombin formation in the presence of platelet release product(s).

\section{Discussion}

The procoagulant effect of blood platelets is known since the earliest days of coagulation research. It was indeed postulated by Bizzozero in his first description of the blood platelets (16). Many later observations confirmed the role of platelets in coagulation (17).

We wanted to investigate what the relative importance of platelet activation is on thrombin generation in a reaction medium that is as close as possible to native platelet rich plasma.

In platelet rich plasma, recalcification causes a burst of thrombin formation after a lag time of $8-10 \mathrm{~min}$. This "spontaneous" thrombin generation is initiated by contact activation, as it is substantially prolonged in factor XII deficient plasma (Fig. 3). The addition of a low amount of thromboplastin $(1: 2,400)$ causes a shortening of the lag phase that preceeds a burst of thrombin formation by $3-5 \mathrm{~min}$. Because this phenomenon was not observed in platelet poor plasma, it indicates that there is a combined action of thromboplastin and platelets. This effect is mediated by factor VII because it is not seen in factor VII deficient plasma (Fig.2). Hirudin, which is a specific inhibitor of thrombin without known effect on platelets per se is able to prolong the lag, time (Fig.2). Thrombin on the other hand shortens the lag time (Fig. 3). These observations indicate that the effect of thromboplastin on the lag time is mediated by thrombin. The effect of traces of thrombin in advancing the appearance of a thrombin burst in whole blood has been reported as early as 1953

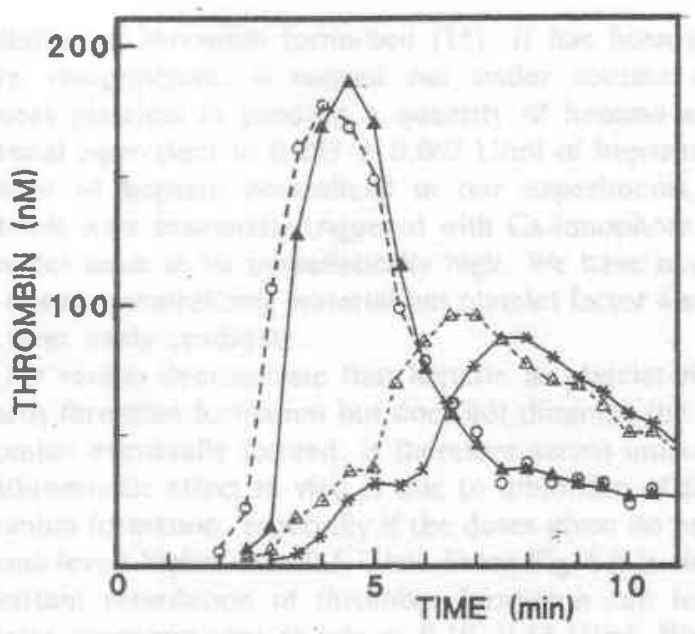

Fig. 5 The effects of phospholipid and factor $\mathrm{V}_{\mathrm{a}}$ on thrombin generation in platelet rich plasma. Symbols used: $(\boldsymbol{\Delta}), 40 \mu \mathrm{M}$ phospholipid (20\% phosphatidylserine $180 \%$ phosphatidylcholine) and no thromboplastin: (O) , $40 \mu \mathrm{M}$ phospholipid ( $20 \% \mathrm{PS} / 80 \% \mathrm{PC}$ ) and $1 / 2.400$ diluted thromboplastin; $(\triangle), 10 \mathrm{nM}$ factor $V_{\mathrm{a}}$ and no thromboplastin and $(\star)$, no addition

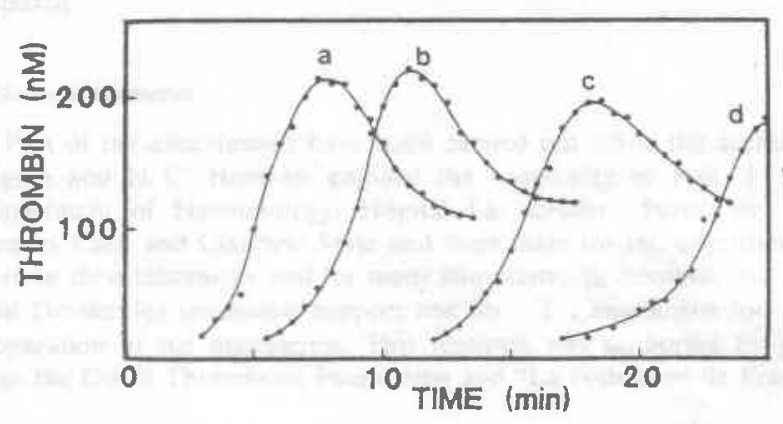

Fig. 6 The influence of unfractionated heparin on thrombin generation in platelet rich piasma. Thrombin generation was started by the addition of thromboplastin $(1 / 2.400)$ in the presence of (a). no heparin: (b). $0.1 \mathrm{U} /$ $\mathrm{ml} \mathrm{heparin:} \mathrm{(c)} 0.2 \mathrm{U} / \mathrm{mi}$ heparin and (d) $0.3 \mathrm{U} / \mathrm{ml}$ heparin

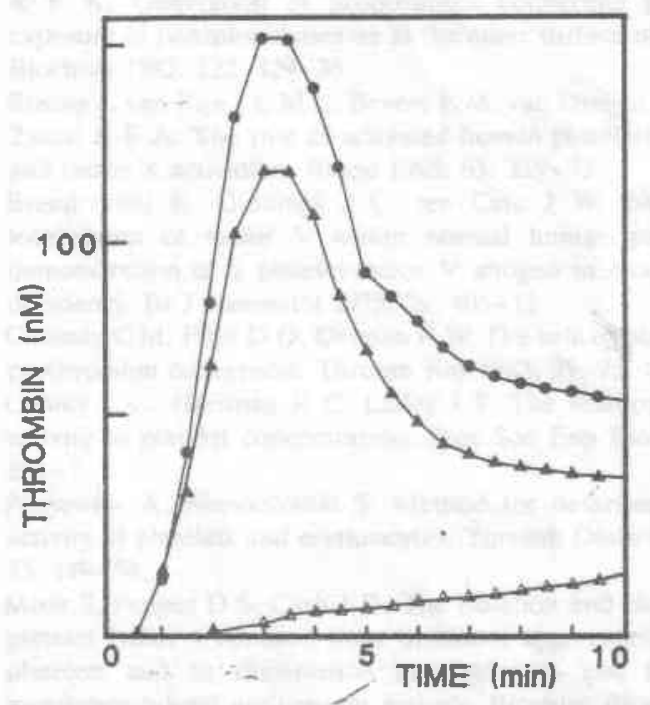

Fig. 7 Neutralization of heparin by activated platelet by $5 \mu \mathrm{M} \mathrm{Ca}$ ionophore (AZ 23187). (•) Plasma obtained by centrifugation of platelet rich plasma activated by $\mathrm{Ca}$-ionophore, to which $0.1 \mathrm{unit} / \mathrm{ml}$ heparin has been added. (A) 0.4 unit/mi heparin. $(\Delta)$ : control with non activated platelet poor plasma with addition of $5 \mu \mathrm{M}$ Ca-ionophore and $0.1 \mathrm{U} / \mathrm{ml}$ heparin 
y Biggs and Macfarlane. The mechanism behind this phenomenon has remained obscure, however (17). The occurrence of low concentrations $(0.1-1 \mathrm{nM})$ of thrombin in blood before a thrombin burst occurs that leads to coagulation has been demonstrated by Shuman and Majerus (18).

Two products from activated platelets can contribute directly to thrombin generation: phospholipids and factor $V$. We added procoagulant phospholipid or activated factor $\mathrm{V}$ in quantities that are roughly equivalent to the maximal contribution of $3 \times 10^{8}$ platelets/ml. The effect of factor $V_{a}$ appeared to be minor compared to that of phospholipids (Fig. 5). The combined effect of phospholipid and factor $V_{a}$ was hardly greater than that of phospholipid alone; the lag time was shortened by $30 \mathrm{sec}$ compared to the curves with phospholipid alone and the peak activity was not significantly increased. In order not to overload Fig. 5 these data are not shown. We conclude that it is probably the phospholipid produced by the platelets that enhances thrombin formation.

Bevers et al. (2) have shown that isolated platelets are capable of producing procoagulant phospholipids at the outside of their membrane ("flip-flop"). Under these experimental -conditions $\left(10^{6}\right.$ platelets $\left./ \mathrm{ml}\right)$ thrombin $(2 \mathrm{nM})$ needs the simultaneous presence of collagen in order to provoke the reaction. Rosing et al. (3) have shown that at higher platelet concentrations thrombin alone is an efficient trigger. At the platelet concentration we used $\left(3 \times 10^{8}\right.$ platelets $\left./ \mathrm{ml}\right)$ the requirement for collagen is abolished. Indeed, the addition of collagen in our system, either with or without stirring had no effect on thrombin generation in the presence and in the absence of thromboplastin (results not shown)

We can summarize our view of the course of events as follows. In platelet rich plasma, when coagulation is triggered by $\mathrm{Ca}^{2+}$ and a low concentration of thromboplastin, the system immediately after recalcification can be regarded as platelet poor piasma, in which inactive platelets are suspended. Thromboplastin causes small amounts of thrombin to be formed. These induce a procoagulant reaction in the platelets that starts an explosive thrombin formation. From the known procoagulant activities of the platelets. the production of procoagulant phospholipids is the most likely candidate for the explanation of this effect. The factor $V$ contributed by the platelets seems less important for thrombin generation than the phospholipid is. An additional effect of thrombin on the activation of factor $V$ und VIIl during the lag time cannot be excluded. Biggs and Nossel (19) and Josso and Prou-Wartelle (20) described that at low thromboplastin concentrations the factor VII dependent activation of factor IX contributes to thrombin formation. Østerud and Rappaport proved the existence of this mechanism without reasonable doubt (21). We could show (experiments to be reported separately) that in our system, dilutions of thromboplastin of 1:500 and higher cause an increasingly important contribution of the VII $\rightarrow$ IX $\rightarrow \mathrm{X}$ pathway. This means that we cannot exclude the possibility of an additional contribution of factor VIII activation to the phenomena observed. The explosion of thrombin is limited by exhaustion of the prothrombin available

The effect of unfractionated heparin on thrombin generation in platelet rich plasma is significantly different from that in platelet poor plasma. In platelet rich plasma the main feature of heparin addition is a prolongation of the lag time of thrombin formation whereas in platelet poor plasma the decrease of the peak amrount of thrombin is the predominant phenomenon (15)

From Fig. 7 it follows that platelets at a physiological concentration contain amounts of heparin neutralizing material that are capable of virtually complete neutralization of $0.5 \mathrm{U} / \mathrm{ml}$ of heparin. This represents a heparin concentration that in rigorously platelet and PF 4 free plasma will cause more then $95 \%$ inhibition of thrombin formation (15). It has been shown that mere venipuncture, if carried out under routine conditions, induces platelets to produce a quantity of heparin neutralizing material equivalent to $0.183 \pm 0.067 \mathrm{U} / \mathrm{ml}$ of heparin (22). The amount of heparin neutralized in our experiments, in which platelets were maximally triggered with $\mathrm{Ca}$-ionophore, therefore does not seem to be unrealistically high. We have not identified the heparin neutralizing material but platelet factor 4 seems to be the most likely candidate.

Our results demonstrate that heparin in platelet rich plasma retards thrombin formation but does not diminish the amount of thrombin eventually formed. It therefore seems unlikely that its antithrombotic effect in vivo is due to inhibition of the bulk of thrombin formation, especially if the doses given do not result in plasma levels higher than $0.5 \mathrm{U} / \mathrm{ml}$. From Fig. 6 it is clear that an important retardation of thrombin formation can follow from heparin concentrations as low as $0.10-0.15 \mathrm{U} / \mathrm{ml}$. We postulate that this retardation is instrumental in obtaining an antithrombotic effect with low doses of heparin. On basis of the data of van Putten et al. (22) we can assume that a circulating heparin concentration of $0.1-0.2 \mathrm{U} / \mathrm{ml}$ will hardly be detected by routine laboratory methods. This accounts for the difficulty in finding a laboratory correlate to the antithrombotic action of low dose heparin

\section{Acknowledgements}

Part of the experiments have been carricd out while the authors. $\mathrm{S}$ Béguin and H. C. Hemker. cnjoycd the hospitality of Prof. 3. Cacn. Department of Hacmatology. Hopital Lariboisicre. Paris. We thank Jacques Caen and Claudine Soria and their team for the opportunity to work in their laboratory and for many stimulating discussions. We thank Paul Devilćc for invaluable support and Mrs. T. Camphuisen for expert preparation of the manuscript. This research was supported by grants from the Dutch Thrombosis Foundation and "La Fondation de France"

\section{References}

1 Kloprogge E. de Haas G M. Gorter G. Akkerman J W N. Properties of PAF-acether-induced platelet aggregation and secretion. Studies in gel-filtered platelcts. Thromb Res 1983; 29: 595-609.

2 Bevers E M. Comfurius P. van Rijn J L M L. Hemker H C, Zwaal R F A. Generation of prothrombin converting activity and the exposure of phosphatidyiserine at the outer surface of platelets. Eur J Biochem 1982; 122; 429-36.

3 Rosing J. van Rijn J L M L. Bevers E M, van Dieijen G, Comfurius P, Zwaal R F A. The role of activated human platelets in prothrombin and factor $\mathrm{X}$ activation. Blood 1985; 65:319-32

4 Breederveld K. Giddings J C. ten Cate J W. Bloom A L. The localization of factor $V$ within normal human platelets and the demonstration of a platelet-factor $\mathrm{V}$ antigen in congenital factor $\mathrm{V}$ deficiency. Bт J Haematol 1975; 29: 405-12.

5 Chesney C M. Pifer D D, Colman R W. The role of platelet factor $\mathrm{V}$ in prothrombin conversion. Thromb Res $1983 ; 29: 75-84$.

6 Conley L C. Hartman R C, Lalley J S. The relationship of heparin activity to platelet concentration. Proc Soc Exp Biol Med 1948: 69: $284-7$

7 Poplawski A. Niewarowski S. Method for determining antiheparin activity of platelets and erythrocytes. Thromb Diath Haemorrh 1965 13: $149-54$

8 Moor S, Pepper D S. Cash J D. The isolation and characterization of platelet factor 4 released from thrombin aggregated washed human platelets and its dissociation into subunits and the isolation of membrane-bound antiheparin activity. Biochim Biophys Acta 1975; 378: $370-84$.

9 Walsh P N. Platelet mediated trigger mechanisms in the contact phase of blood coagulation. Sem Thromb Hemostas 1987; 13: 86-94.

10 Walsh P N, Griffin J H. Contributions of human platelets to the proteolytic activation of blood coagulation factors XIl and XI. Blood 1981: $57: 106-18$ 
11 Jesty $J$. Nemerson Y. Purification of factor VII from bovine plasma. Reaction with tissue factor and activation of factor X. I Biol Chem 1974: 249: 509-15.

12 Owren P A, Aas K. The control of dicumarol therapy and the quantitative determination of prothrombin and proconvertin. Scand $\mathrm{J}$ Clin Lab Inv 1951; 3: 201-18.

13 Hemker H C. Willems G, Béguin S. A computer assisted method to obtain the prothrombin activation velocity in whole plasma independent of thrombin decay processes. Thromb Haemostas 1986; 56: 9-17.

14 Tracy P B, Eide L, L, Bowie E J W, Mann K G. Radioimmunoassay of factor $\mathrm{V}$ in human plasma and platelets. Blood 1982; 60: 59-63.

15 Hemker $\mathrm{H}$ C. The mode of action of heparin in plasma. In: Thrombosis and Haemostasis. Verstraete M. Vermylen J, Lijnen R. Arnout J (eds). Leuven University Press, Leuven 1987; pp 17-36.

16 Bizzozero G. Sur un nouvel élément morphologique du sang chez les mammifères et son simportance dans la thrombose et dans la coagulation. Archiv Ital Biol 1882; 345-62.

17 Biggs R, Macfarlane R G. Human Blood Coagulation. Blackwell Scientific Publications, Oxford. 1953.

18 Shuman M A. Majerus P W. The measurement of thrombin in clotting blood by radioimmunoassay. J Clin Invest 1976; 58: 1249-58.

19 Biggs R. Nossel H L. Tissue extract and the contact reaction in blood coagulation. Thromb Diath Haemorrh 1961: 6: 1-14.

20 Josso F, Prou-Wartelle O. 4. Interaction of tissue factor and factor VII at the earliest phase of coagulation. Thromb Diath Haemorrh 1965: Suppl. 17: 35-44.

21 Østerud B, Rappaport S I. Activation of factor IX by the reaction product of tissue factor and factor VII: additional pathway for initiating blood coagulation. Proc Natl Acad Sci USA 1977; 74: $5260-4$

22 van Putten J. Ruit M. van de Beunis M. Hemker H. C. Heparin neutralization during collection and processing of blood inhibited by pyridoxal 5'-phosphate. Haemostasis 1984; 253-61.

Reccived March 8. 1988 Accepted after revision September 21. 1988 